\title{
RETRACTED ARTICLE: A stoic defence of rational suicide
}

\section{Floris Tomasini}

Published online: 4 July 2012

(C) The Author(s) 2012. This article is published with open access at Springerlink.com

The author withdraws this paper due to errors in referencing. 